1995

\title{
In Other Words: Putting Sex and Pornography in Context
}

Allan C. Hutchinson

Osgoode Hall Law School of York University, ahutchinson@osgoode.yorku.ca

\section{Source Publication:}

Canadian Journal of Law and Jurisprudence. Volume 8, Number 1 (1995), p. 107-138.

Follow this and additional works at: https://digitalcommons.osgoode.yorku.ca/scholarly_works (c) (1) $(9$

This work is licensed under a Creative Commons Attribution-Noncommercial-No Derivative Works 4.0 License.

\section{Recommended Citation}

Hutchinson, Allan C. "In Other Words: Putting Sex and Pornography in Context." Canadian Journal of Law and Jurisprudence 8.1 (1995): 107-138.

This Article is brought to you for free and open access by the Faculty Scholarship at Osgoode Digital Commons. It has been accepted for inclusion in Articles \& Book Chapters by an authorized administrator of Osgoode Digital Commons. 


\section{In Other Words: Putting Sex and Pornography in Context}

Allan C. Hutchinson

We cannot ask reason to take us across the gulfs of the absurd. Only the imagination can get us out of the eternal present.

-Ursula Le Guin'

Law controls sexuality not only by its coercive powers, but also through its discursive constructions. While there are other social forces and influences in play, sexual identities and sexual practices are framed within the ample reach of law's linguistic domain. As well as enforcing prevailing moral norms and deciding the scope of socially-validated sexual behaviour, law also determines what counts as sex in the tableau of human behaviour. Although the relationship of law, sexuality and sex is always ideologically fraught, it is particularly so in regard to graphic representations of sex and sexuality. The debate around this so-called pornography hits a very sensitive nerve in the body politic. Indeed, in recent years, few social practices have managed to arouse as much intellectual angst and political anger as pornography. In part, this is because the debate seems to cut across traditional political lines; it sets traditional enemies against each other and fosters strange alliances among them. None of this should be too surprising as pornography touches profound issues which strike at the very heart of those dilemmas, difficulties and denials that comprise the human condition.

In this essay, I want to take a postmodem cut at the pomography debate. To date, there has been much heat generated, but very little light. Antagonists seem only too willing to take extreme positions and to defend their essentialist turf come hell or high water. In contrast, I want to place pornography in a much more nuanced and less dogmatic context in order to get a better handle on the contested notions of sexuality and sex that underlie and energise the academic debate and political furor around it. To do this, I will focus on the contribution of one particular and influential scholar whose writings and activities have provoked the most critical interest and had the most political effect-Catharine MacKinnon. Through an examination of the ideological engagement around her anti-pornography work, I hope to elucidate the force and worth of a postmodern approach to issues of sex, sexuality and law. Concerned as it is with the discursive dimension of social living, a postmodern approach is particularly suited to the debate over pornography whose argumentative terrain is "a darkling plain ... where ignorant armies clash by night"

I am very grateful to Harry Arthurs, Adam Bernstein, Brenda Cossman, Les Green, Robert Maisey, Jim Smith and Wendy Rambo for their encouragement and help. Spocial thanks to Pam Marshall who showed me, as she put it, that "it is possible for a feminist to have sex as vell as gender." A revised version of this essay will appear as a chapter in a forthcoming book, entilled Swimming With Turtles: Law, Politics and Postmodernism.

1. U. Le Guin, Dancing at the Edge of the World (New York: Grove Press, 1989) at 45.

2. M. Amold, "Dover Beach" in Amold: Poetical Works (London: Oxford University Press, 1950) at 212. 
and the dogmatic language of orthodoxy prevails.

I.

Catharine MacKinnon is the voice of radical feminism in law. Although her views are by no means accepted by all radical legal feminists, they do tend to set the terms of current debate and orthodoxy. In a prolific series of books and articles, she has initiated and developed a thesis that stands as the most rigorous and uncompromising challenge to the patriarchal theories and practices of contemporary society. Hers is a feminism that is unmodified and unapologetic in its radicalness: it is academic scholarship as a form of social activism. ${ }^{3}$ Emphasizing the importance of tying together the abstract and the concrete, she has struggled to demonstrate that sexism is a matter of political domination and material subordination, not sexual difference and moral error. MacKinnon has devoted her life and energies as teacher, scholar, litigator, reformer, journalist and activist to the unrelenting campaign against women's oppression. Few people have had the impact and aroused the anger that Catharine MacKinnon has in the last 15 years. Apart from her substantive contributions to the debates over abortion, pornography, rape and the like, she has managed to change the very standards of scholarship as she exceeds them. To read her work is to engage in an experience that is itself draining and unsettling.

In her most recent offering, Only Words, ${ }^{4}$ MacKinnon brings to bear the full weight of her feminist critique on the debate over the continued constitutional protection afforded to pornography in the United States. Combining epistemological scrutiny with empirical analysis, she assembles a sustained set of arguments that aim to demonstrate that pornography is the eroticization of sexualized violence and to reveal the doctrinal and political complicity of law in thwarting efforts to eradicate it. To do this, she operates along several complementary axes of criticism. First, she insists that pornography is not speech, but is an activity that falls outside the First Amendment: it is an act of sexual violence against women. (3-41) Secondly, even if it is treated as speech, it is more like sexual harassment than anything else and, like sexual harassment, does not qualify for constitutional security. (45-68) Thirdly, although it might be considered to fall within the confines of free speech, the First Amendment must be read with and against the Constitution's commitment to equality; there is no obvious or compelling reason why the First Amendment trumps the Fourteenth Amendment in the constitutional game of cards. (71-110)

At the theoretical core of her uncompromising position is the assertion that words speak as loud as action, that the pornographic words of men are acts of violence that cause harm, and that such harm has a measurable and physical effect on women. With characteristic directness and ruthlessness, she contends that, as the

3. See Feminism Unmodified: Discourses on Life and Law (Cambridge, MA: Harvard University Press, 1987) [hereinafter Feminism] and Toward a Feminist Theory of the State (Cambridge, MA: Harvard University Press, 1989) [hereinafter State].

4. C. MacKinnon, Only Words (Cambridge, MA: Harvard University Press, 1993) [hereinafter parenthetically referred to by page number in the text]. 
expression of sexual words through pornography is "a sex act in itself" (58) and "can be sexual assault" (68), it is not deserving of constitutional valorization. As such, MacKinnon has assembled an audacious set of claims that warrants sustained and critical attention. Yet, for all her emphasis on the power of words and their harmful effects, MacKinnon falls victim to the very essentialist and objectivist epistemology from which she is most at pains to distance herself. The problem with MacKinnon is that she ultimately fails to understand that words are all that there is and that the equation of the word with the act is to believe that there really are 'acts' out there that speak for themselves and that go around 'named' in the universe outside of social ways of knowing and speaking. Paradoxically, she takes words both too seriously and not seriously enough. She takes them too seriously because she contends that the utterance of words is the equivalent of the act that it describes. On the other hand, she takes them not seriously enough because she maintains that the meaning of any act can be fixed and apprehended outside the dominion of words. In other words, she fails to appreciate the full significance and import of the assertion that there are only words. While she is correct to reject the traditional view that "pictures themselves do nothing" (5), she is mistaken in holding to the equally extreme view that " $[t]$ o say it is to do it, and to do it is to say it" (33): to treat words and action as one and the same is as bad as treating them as entirely unrelated.

What follows is a postmodem reading of MacKinnon's work, with especial reference to Only Words. I intend to take MacKinnon at her word and to accept her invitation to follow through on the claim that sexual violence is only words. In so doing, I pursue her commitment to change the way people talk and, therefore, to change the way people are and, more importantly, can become. As an exercise in postmodern scholarship, I want to take seriously the hermeneutical insight that "there is no way to think about ... the world ... except by using our language." In other words, I will explore and explain what follows, if anything, from treating rape and pornography as a language. Contrary to much received wisdom, I believe that a postmodern approach does not trivialize or de-politicize violence against women. Apart from being the most intellectually compelling way of proceeding, it underlines the inescapably political, contestable and, therefore, transformable character of those violent acts and misogynist practices. A postmodern approach to law,

5. R. Rorty, Consequences of Pragmatism (Minneapolis: University of Minnesola Press, 1982) at xix. At this point, it seems important to state the position from which I enter the debate. I am, among other things, a white, heterosexual, middle-class father of three daughters. For further details on my identity and how and why it might matter, see A. Hutchinson, "Identity Crisis: The Politics of Interpretation" (1992) 26 New Eng. L. Rev. 1173. Although I went to challenge the existence of sexism, racism and homophobia in society, this no more entitles me to call myself a feminist than being against anti-semitism entitles me to call myself Jevish. A similar argument is made in G. Peller, "Race Consciousness" (1990) Duke L.J. 758.

Also, I do not claim any privileged status in my own efforts to confront sexism, racism and homophobia. Being brought up and living in a sexist, racist and homophobic socicty means that my own identity is tied in with sexist, racist and homophobic practices and beliefs. However, as I try to show in the essay, this does not mean that I am forever condemned to be sexist, racist and homophobic or that I can miraculously reach a state of mind or modus vivendi that is purged of all sexist, racist and homophobic traces. The challenge is to recognise those constraints and work to confront them transformatively. 
politics and pornography represents the least worst intellectual complement to the practical aspirations of a democratic society which takes seriously the need both to enhance the diversity of political discourse and to encourage the equality of social roles.

II.

At the heart of MacKinnon's critique is the claim that words are never only words: they are actions that cause real and lasting harm to people in the world. This, in and of itself, is hardly novel or controversial: civil and criminal law has long recognised the power of words (defamation and threats) and the need to protect people from the harm that they can do (financial loss and emotional distress). Nor is her claim that pornography depicts women "as less than human" (62): this is a view shared by many of her opponents on the separate question of whether it should nonetheless be granted constitutional status. The radical edge of her critique is to be found in her absolute conviction that "[u]nwelcome sex talk is an unwelcome sex act" (46) and that "if there is anything that only pornography can say, that is exactly the measure of the harm that only pornography can do" (22). Indeed, she leaves little doubt of her intent when she insists that "pornography is no less an act than the rape and torture it represents" (29). Accordingly, MacKinnon is clear not only that pornography should be prohibited as a vicious act that causes untold harm to women, but also that such anti-pornography legislation ought not to be constitutionally proscribed.

Throughout Only Words, MacKinnon claims to hold a view that language is not a neutral medium through which the world is represented to us, but that "[s]ociety is made of words" (30) and "speech can be an exercise of power which constructs the social reality in which people live" (31). In accepting this understanding of language as a creative and constitutive component of reality, she seems to recognise that there is no reality that can be experienced in its essential or unmediated state:

Together with all its material supports, authoritatively saying someone is inferior is largely how structures of status and differential treatment are demarcated and actualized. Words and images are how people are placed in hierarchies, how social stratification is made to seem inevitable and right, how feelings of inferiority and superiority are engendered, and how indifference to violence against those on the bottom is rationalized and normalized. Social supremacy is made, inside and between people, through making meanings. $(31)^{6}$

Nevertheless, despite these promising and convincing assumptions that "society is made of language" (106), MacKinnon seems to forget their force and implications when she moves from statements of general principle to a substantive discussion

6. Whereas MacKinnon insists that "[p]ostmodernism ... is predicated on obscuring ... this function of language in social hierarchy" (123), I maintain that this function is a mainstay of a postmodernist appreciation of discourse. However, less hangs on whether MacKinnon and I disagree over what to call this view of discourse than on the more significant differences over what it means to adopt such a discursive understanding of social reality. 
of pornography. From a non-essentialist and organic account of discourse and reality, she slips back into a very objectivist and static account of reality. It is difficult to read her book without believing that, for MacKinnon, there are a whole set of entities, activities and assessments-women, men, sex, experience and oppression-that are real in the sense that they are apprehendable and have meaning outside of language: they are knowable in themselves without interpretation. Contrary to her primary thesis that there are only words, she argues that actions speak not only louder than words, but that they speak for themselves in a language that is universal and intelligible to all; only the wilfully hard of hearing are deaf to its message. Indeed, she goes as far as to say that "I am asking you to imagine that women's reality is real-something of a leap of faith in a society saturated with pornography, not to mention an academy saturated with deconstruction" (7). It is the affirmation of objective realism on a grand scale.

By arguing that "[b]eyond bringing a message from reality, [pomography] stands in for reality; it is existentially being there" (25), MacKinnon adopts a very classical notion of Truth and Reality that is at odds with her discourse-based protestations.' She completely eschews any interpretive space between what is said and what there is. This is tantamount to an ontological account of truth (what is true is what exists) that is the philosophical opposite of the pragmatic epistemology (what is true is what can be said) that she claims to hold. For her, the language of pornography has meaning in and of itself; its (bad) nature and effects speak for themselves and need no interpretation. Anyone who fails to recognise this is speaking falsity to truth and is complicit in the violence that pornography does to women.

In driving home her opposition to pornography, MacKinnon allows her ideological zeal to compromise her intellectual judgment and, in the process, manages to subvert her own political crusade. The espousal of such an essentialist epistemology is not only of suspect philosophical validity, but it is of dubious political merit. The consequence of MacKinnon's theoretical classicism is to consign the meaning of pornography, sex and oppression to the level of the metaphysical, something that can be named and understood, but not challenged or transformed. These acts and situations become part of the human condition, beyond the revision of human societies, only to be noted and negotiated around. They are no longer thought of as social constructs for which society has to take responsibility for making and, importantly, re-making. In a perverse turn of events, Mackinnon succeeds in de-politicizing pornography and oppression as the basic theoretical move in her political campaign to eradicate them. In contrast, a postmodern account ensures that pornography and the debate around it remain firmly situated on the contested terrain of politics, with all the usual disabling risks as well as the enabling opportunities that attend the play of social and historical forces.

Of course, none of this means, as MacKinnon implies, that postmodemists like myself hold that "[v]alue can be found in anything" (88) and that reality is nothing but a dream. To conclude that it is only words is not to trivialize politics, but to

7. For a good account of the failure of the classical paradigm of truth, see B. Allen, Truth in Philosophy (Cambridge, MA: Harvard University Press, 1993). 
say the most profound thing that there is to say. MacKinnon has to accept that, if words can be acts, then acts not only can be words, but must be construed through words if we are to make any sense of them. People do not look at reality through language, but always with language and at language. Social facts never stand free of the social theories that bring them into existence and make them available for perusal and protest. How we comprehend the world is always part of and inseparable from that world. The imagery projected on the world is never detachable from that world so that the world can be viewed and experienced in some unencumbered and pristine way. Of course, this is not to subscribe to the absurdly idealistic view that there is no world that functions outside of language and that reality is "begot of nothing but vain fantasyl Which is as thin of substance as the air $\backslash$ And more inconstant than the wind." I argue that, beyond immediate and personal sensations of the physical environment, the world is only accessible and knowable through language; life is an interpretive activity. While communicative practices are not the only kind of practices, they do frame and give meaning to other practices and are important for that reason. Socially constructed does not mean 'unreal' because socially constructed is as real as it gets. Access to the world is available only through the mediating force of language. Truth and reality are socio-historical artifices that can only be thought about through language. In other words, when it comes to truth and reality, there are only words.

Characteristically, what amounts to a postmodern treatment of any subject is always open to question. If it has any hallmark, it is a thoroughgoing skepticism toward the belief that there are any essential, final or foundational truths. It takes seriously the idea that truth is forever beholden to the discursive regimes through which it is apprehended and validated. Always attentive to its social situation and historical location, it harbours a deep mistrust of generalizations and encourages a preference for particularity. As Lyotard put it, postmodernism cultivates "an incredulity towards meta-narratives"9 whether they are about History, Reason, Truth, Reality, Oppression; Identity or whatever. Of course, postmodernism is sceptical about all things, including scepticism itself. This does not mean that postmodern sceptics disbelieve everything: this is as absurd as suggesting that absolutists believe everything. They have beliefs about history, reason, truth, reality, oppression, identity or whatever, but they hold them in a conditional and provisional way. This does not mean that postmodernism has a relativist epistemology, but that it has no epistemological theory at all. Truth and meaning cannot be understood apart from the customary and extant procedures of discursive justification. ${ }^{10}$ The desire for objectivity is nothing more (and nothing less) than the wish for the greatest possible intersubjective agreement and human cooperation.

8. Shakespeare, Romeo and Juliet, Act 1, Sc. iv. I agree with Dr Johnson that only mental experiences are real. Kicking a stone with great force, he recoiled and declared "I refute it thus."

9. J-F. Lyotard, The Postmodern Condition, trans. G. Bennington \& B. Massumi (Minneapolis: University of Minnesota Press, 1984) at xxiv.

10. See R. Rorty, "Solidarity or Objectivity?" in J. Rajchman \& C. West, eds, Post-Analytic Philosophy (New York: Columbia University Press, 1985) 3 at 5-7 and R. Rorty, Philosophy and the Mirror of Nature (Princeton: Princeton University Press, 1979) at 357-94. 
Accordingly, my challenge is not to the reality of pornography, sex or oppression, but to the meaning to be attributed to that reality and the reality of that meaning. Whereas MacKinnon presents an account that is ahistorical, universal and totalizing, I want to suggest that the practices of pornography, sex and violence are much more historical, contingent and diffuse. As such, they are much more open to diverse interpretation and, therefore, political disruption. By opening up the discourse of pornography and sexual violence, it becomes possible to work the interpretive spaces to transformative effect. This is not to deny the main thrust of MacKinnon's work in its entirety, but to re-state it in a postmodern way that makes it more fragmented, less essentialist and, therefore, more open to interpretation and re-appropriation. It does not draw a line in the history's ground and ask people to choose sides in a once-and-for-all way. Instead, by not treating pornography and rape as static and fixed, postmodernism is better able to understand them as "a process[es] to be analyzed and undermined as [they] occur."'" In this way, both women and men can be galvanized to combat women's continued oppression rather than accept it as part of the inevitable aspect of contemporary living. It is the burden of the rest of the essay to give greater substance and specificity to these disagreements with MacKinnon.

III.

An oblique way to get at the vital point - that truth and meaning are only understandable and meaningful through attention to particular contexts which themselves are never beyond interpretation-is to ask about the status of MacKinnon's own text and its meaning. In particular, I want to tackle the much vexed question of why Only Words (and her lectures) does not amount to pornography and is, therefore, not productive of harm to women. As replete as they are with graphic references to sexual violence and pornographic material, what makes MacKinnon's writings immune to the force of her own condemnation of such words? For instance, she repeats verbatim several racial epithets and pornographic threats-"Nigger Die" (52) and "I am going to fuck you even if I have to rape you" (134)- that she clearly believes to be causative of terror and sexually violative. Indeed, in repeating these words, what absolves me of blame or responsibility for their general pomographic effects? While these questions may appear initially as something of a cheap shot, I believe that their consideration and an elaboration of their possible answers goes to the root of MacKinnon's flawed account of power, language, identity and change.

11. S. Marcus, "Fighting Bodies, Fighting Words: A Theory and Politics of Rape Prevention" in J. Butler \& J. Scott, eds, Feminists Theorize the Political (New York: Routledge, 1992) 385 at 388. While I have used the term 'pornography' for the sake of convenience, there is something very essentialist and judgmental about it: it connotes what is already considered to be harmful and deviant. It would be more useful and effective to talk about sexually-explicit representations which, like any other kind of representations, is neither intrinsically good or bad. What is and is not a pornographic representation (as opposed to, say, erotica) is a context-specific and constantly contestable political assessment; it does not have the universalized and incontestable thereness of traditional assertions. See M.J. Frug, Postmodem Legal Feminism (New York: Roulledge. 1992). 
Presumably, MacKinnon's response to such charges might be that her recounting of such words is not pornographic because her reason for doing it is to condemn such practices, not to glorify them or, importantly, not to "[get] off on writing and sending the note and envisioning the recipient reading it" (58). In other words, she might defend herself by claiming that Only Words is "educational or revelatory or subversive or liberating or ...' As for my own repetition of her words, she might want to know more about what my intentions are-Am I merely being sensationalist? Am I acting in good faith? Do I 'get off' on it? In both cases, the likely answers would probably (and, in my case, certainly) involve an appeal to the broader context in which these words were uttered. The meaning and responsibility for their effects might depend on a variety of factors, including the speaker's intention, the identity of the speaker, the medium of expression, the audience addressed, the place and timing of speaking, etc. The very 'saidness' of the words would not be decisive or determinative of their meaning or the consequences that might flow from them: the words do not speak for themselves.

The point of this hypothetical inquiry, of course, is to reinforce the view that truth, meaning, reality and other things are only intelligible within larger discursive frameworks and social practices. As MacKinnon says, "[t]his mental element makes events into discrimination which might otherwise be regarded as coincidence or accident" (51). In other words, she concedes that acts and events do not have any separate meaning or free-standing significance; it is such things as "mental location" (51) and their larger interpretive contexts that permit the ascription of meaning and warrant certain presumptions about their value. Of course, this is not to suggest that, while words themselves do not have any fixed or essential meaning, they can acquire it through comprehending their appropriate context. Like the words that they give meaning to, contexts and intentions are not themselves capable of final or essential definition. They are as contingent and provisional as the social and historical forces that frame and change them. It is not that there can be no determinacy, it is that there is no reliable or abiding way to describe once-and-for-all the historicized relation between a text and its context.

As expected, MacKinnon's essentialist line of argument did not find favour in many circles: it brought out the most scathing and savage reviews. While the radical nature of MacKinnon's work, in both its force of expression and its bluntness of content, was guaranteed to give rise to hostility and controversy, the response by Carlin Romano was unlikely to have been anticipated by even the most hardened observers of the pornography or feminist debates. His review was as inflammatory and premeditated as MacKinnon's book was incendiary and calculated: it was a Molotov cocktail thrown into the already blazing fires of the intellectual establishment. ${ }^{2}$ In an extended rejection of MacKinnon's position, Romano constructed a scenario in which MacKinnon is not only raped, but in which the rape is reported in lavish detail in the media.

Unfortunately, the conflagration that followed the review managed to consume the immediate possibility of any sensible or nuanced discussion of the substantive

12. Carlin Romano, "Between the Motion and the Act" The Nation (15 Nov. 1993) 563. 
issues at stake; reasoned debate and productive disagreement were displaced by profound rancour and mutual allegations of bad faith. As always in controversies of this kind, it was a matter of allegiance in which the middle ground was neither available nor accessible. A taking of sides was all that there could be: you were either for MacKinnon and against Romano or for Romano and against MacKinnon. There was (and is) little sense in which it is possible to be: on some issues, for MacKinnon and for Romano; on other issues, against MacKinnon and against Romano; and on still other issues, neither for nor against either MacKinnon or Romano. Pornography, the debate on pornography, and the debate on the debate on pornography deserve to be taken much more seriously than the polarizing dynamic of the Romano-MacKinnon debacle.

Romano's essay postulates a fictitious series of events in which, having read her book, he forms the opinion that "understanding her support for censorship of pornography requires raping her." When he attempts to put his plan into action, he is talked out of it by the cornered MacKinnon who insists that "exposing her to pornography would be just as effective." Instead, he writes a review of the imagined rape "in savage, pornographic Bret-Easton-Ellis detail." In order "to be provocative," he does not reveal that the rape is imagined. The review is published and he is arrested for rape. Another critic, Dworkin Hentoff, ${ }^{13}$ reads the review and decides that he must rape MacKinnon before he can properly evaluate her book. Unlike Romano, he actually carries through with his intention and rapes MacKinnon. He writes and publishes his review, again "in long-winded, pornographic detail." It is an erudite essay that frames his rejection of MacKinnon's claims in a broader intellectual discourse on democracy and free speech. When Hentoff and Romano meet in the cells while awaiting arraignment, Romano thinks to himself: "Not fair ... What I did was different."

In a less disturbing and more conventional nature, the rest of Romano's review is devoted to supporting his conclusion that "her reasoning is often specious, her empirical claims are often suspect, her values are dogmatic and her view of sex and the good society is ravishingly insular." For him, no matter how degrading and demeaning it is, pornography is the price that American society has to pay for the preservation of a public agora in which debate is robust and unfettered; censorship is something for revisionists and crypto-fascists. By exalting the ideology of victimisation, Romano believes that MacKinnon is "an authoritarian in the guise of a progressive" and "threatens to become the Lyndon LaRouche of sexual discrimination law."

The reaction to Romano's review of MacKinnon's Only Words was swift and expected. Dozens of letters were sent to The Nation. However, rather than concentrate on the merits of the respective positions over pornography, the harm it causes and its constitutional privileging, the combatants turned the review itself

13. Presumably, this is a veiled reference to Ronald Dworkin and Nat Hentoff, both regular contributors to the New York Review of Books and both committed to a position that is opposed to censorship. See Ronald Dworkin, "Women and Pornography" New York Review of Books (21 Oct. 1993) 36. If this is intended to be funny, one can only assume that Dworkin and Hentoff were not amused. Indeed, Hentoff published a condemnation of Romano's tactics. 
into the central focus of debate. As is so often the case, the issue became as much one of free speech as anything else; the substantive debate about pornography seemed to take a definite second place. The angriest letters demanded that Romano make an unconditional apology. Others remonstrated that, while Romano might have acted in bad taste, he was perfectly entitled to practice the free speech that he so bravely defended. In the face of this, Romano remained largely unrepentant and stated that - "I did worse [than dehumanize her] -I took her seriously."14

In their righteous and fundamentalist response, Romano and his traditionalist cohorts missed the crucial point of Only Words-Romano's review was itself ample and substantial support for MacKinnon's controversial thesis on words-as-harm and of the pornographic tendencies of mainstream American culture. He perpetuated exactly the same kind of vicious and gratuitous sexual violence against women that MacKinnon is at such pains to reveal and revile. The writing and publishing of such a review is not a matter of "[o]ffense" (11), as MacKinnon rightly points out, it is a question of abuse. Romano has abused his power and, in the process, abused MacKinnon. She has been harmed and violated by Romano's review because an act of assault has been perpetuated against her. As she herself put it, "[t]his is a broadside attack on my humanity.... He had me where he wanted me.... He wants me as a violated woman with her legs spread. He needed me there before he could address my work."'s Once again, under the moral protection of free speech, one more man has used his power to demean and hurt another woman. It is a troubling and troubled state of affairs when such harmful and irresponsible conduct can wrap itself in the flag of free speech and occupy the highground of political rectitude.

Yet, along with its excessive and misguided tone, Romano's review also highlights the deep flaws in his and others' traditional understanding of words that MacKinnon is so keen to invalidate. The fact that MacKinnon overstates her case and reaches a conclusion that is the mirror-image of received wisdom about words does not weaken the strength of her challenge to the traditional view that words do not in themselves do anything. If there is a "philosophical crudity" at work in the MacKinnon-Romano exchange, ${ }^{16}$ it is Romano's and not MacKinnon's. He subscribes to a sticks-and-stones-may-break-my-bones-but-names-will-never-hurt-me theory of meaning. In his haste to condemn MacKinnon's view that "talking sex is the same as having sex" (his words), Romano reverts to the untenable and extreme position that words and acts are only barely related and that the world of acts exists largely outside the reach of words. In other words, that there is a realm of ideas that affects acts and their comprehension, but which is largely self-

14. As quoted in R. Lacayo, "Assault by Paragraph" Time (17 Jan. 1994) 37. A sampling of the letters, along with Romano's response, can be found in The Nation (27 Dec. 1993) at 786 and 816. Stanley Fish is the primary proponent of the view that "[f]ree speech ... is not an independent value but a political prize" and that "free-speech principles don't exist except as a component in a bad argument in which such principles are invoked to mask motives that would not withstand close scrutiny." S. Fish, There's No Such Thing as Free Speech (New York: Oxford University Press, 1994) at 102 and 111-12.

15. As quoted in Lacayo, supra note 14.

16. Supra note 12 at 568 . 
sustaining and independent from those acts. In a passage that is typical of Romano's condescending style of argument, he states that:

Like many professionals who deal mainly with language, MacKinnon has a simplistic, text-based notion of expression. If her view were true, we might just as well take the same attitude toward Titian, the Rockies or Mozart. Take down the paintings, knock down the mountains and shut off the orchestras. Let's all go down to the library and read casebook summaries of the beautiful, the sublime and the exquisite. Psssh want a short summary of "Last Tango in Paris"?"?

In adopting such a simplistic view of language, Romano is in good company. Within liberal theorising, language is understood as a neutral medium that is available to all and that stands independently of the ideas and world it is intended to convey or depict; it is the postperson delivering a letter or the librarian handing out a book ${ }^{18}$ Language is a transparent and neutral medium through which the light of meaning shines.

Through a postmodern optic, language is not a transparency through which the world is observed nor a catalogue of labels to be attached velcro-like to the appropriate contents of the world. Social reality, language and intentionality converge and conflict in mutually sustaining and transforming patterns. There is no form of pure communication that merely represents instead of creating. The world is within the language and the language within the world. Language is a social medium. It shapes society and its individuals as they work to reshape it. No one is free to describe the world as they wish; they are always and already constrained by the prevailing ways of speaking. As such, discourse is as much constitutive of reality, both personal and collective, as it is constituted by that society. It is a cultural and political artefact of the first order "in the sense that it serves to constitute an authority structure." 19 Social reality is constantly being negotiated and constructed, re-negotiated and re-constructed. Language is not a system of static symbols, but is a form of social action and history-making. To acquire and exercise a language is to engage in the most profound of political acts. As much feminist literature shows, to name the world is to control it. ${ }^{20}$ Law manages to impose a largely masculinist construction on social life and thereby silences and marginalizes altemative ways of understanding and being in the world. As a particular mode of authoritative discourse, law inscribes its intrinsic values on the world.

17. Ibid. This belief in a cerebral life that is lived only internally, with no effects or consequences for the outside world, is the stuff of "Cartesian fantasy." See Fish, supra note 14 at 132.

18. See T. Hobbes, Leviathan, C.B. MacPherson, ed. (London: Penguin, 1985, c. 1968) at 101 and J. Locke, An Essay Concerning Human Understanding, A. Pringle-Pattison, ed. (Oxford: Clarendon Press, 1924) Bk.3, ch.2. For a more modern and sophisticated account of liberal discourse, see R. Dworkin, A Matter of Principle (Cambridge, MA: Harvard University Press, 1935) at 181-204.

19. J.G.A. Pocock, Politics, Language and Time (New York: Atheneum. 1973) at 15. See, also, G. Peller, "The Metaphysics of American Law" (1985) 73 Cal. L. Rev. 1151. This insight is not new, but the older view did not pursue the political implications of social construction through discourse. See B.L. Whorf, Language, Thought and Reality, J. Carroll, ed. (Cambridge: Technology Press of Massachusetts Institute of Technology, 1956).

20. See, for example, D. Spender, Man Made Language, 2nd ed. (London: Roulledge \& Kegan Paul. 1985). 
Notwithstanding these corrosive faults and disabling flaws, however, there is one major point in Romano's argument that cannot nor ought to be lightly ignored. To do so would be to throw out the proverbial baby with the dirty bathwater. In the same way that MacKinnon's overstating of the relation between acts and words does not prevent her book from operating as a corrective to the traditional view, Romano's understating of the relation between acts and words does not prevent his review from working as a corrective to MacKinnon's radical view. In presenting his pornographic scenario, Romano is obviously intending to expose what he thinks is the absurdity and wrong-headedness of MacKinnon's general thesis that rape and accounts of rape are one and the same thing in terms of the harm that they cause to women. This is surely the case. Although MacKinnon has been hurt by Romano's public and verbal account of her imagined rape, it is not the same hurt, however hurtful it may be, as that of being physically raped by Romano. To equate the two is to run the severe risk of trivializing rape in order to confirm the seriousness of pornography. This is a high price to pay and exacts a significant toll on MacKinnon's political campaign.

Of course, speech is an act and can do obvious physical harm (e.g., loud music as an interrogation technique). Moreover, it is accepted by the law and society at large that the content of words can have a devastating effect on people's reputation and well-being (e.g., by defamation and criminal threats). But it is another matter entirely to contend that an act and its linguistic representation cause harm in the same way and to the same extent. While it is entirely reasonable for MacKinnon to argue that "[u]nwelcome sex talk is an unwelcome sex act" (46) and that "[w]hat pornography does, it does in the real world, not only in the mind" (15), it seems unreasonable to conclude that "pornography is no less an act than the rape and torture it represents" (29). ${ }^{21}$ Again, while it is entirely reasonable for MacKinnon to argue that "[t]alking about sex can be speech, but doing it through words can be sexual assault" (68), it seems unreasonable to conclude that "[t]o say it is to do it, and to do it is to say it" (33). Indeed, it is reasonable to assume that the persons who are the intended audience for "Nigger Die" (52) or "I am going to fuck you even if I have to rape you" (134) would prefer, if they must, to hear this rather than to have it put into effect. Similarly, there is a world of difference between agreeing that 'all men are potential rapists' and treating all men the same as those men who actually are rapists; the former is not the same thing nor deserving of the same opprobrium as the latter. ${ }^{22}$

This is not to deny or trivialize the harm and abuse that such words can inflict; they can be devastating. But I do want to argue that that harm and abuse is not of the same scale as the actual doing of the act that the words describe. Because there

21. There is a reading of this statement that interprets it to mean that pornography, like rape, is a sex act, but that it is not the same kind of sex act as rape. However, in the context of Only Words generally and MacKinnon's overall argument, it is difficult to sustain this reading with any confidence.

22. The issue of what the statement that 'all men are potential rapists' means and implies is of greater significance in any broader evaluation of MacKinnon's work. See below in text at pages 119 . 121. 
is a difference between the pornographic word and the violent act does not mean that the word does not carry its own hurt that can be severe and enduring. ${ }^{3}$ Indeed, some kinds of rape-descriptions might be more harmful to particular women than other kinds of rapes. However, it is always more harmful for a woman to be raped than to have that very rape described to her. To argue generally that "[t]o say it is to do it, and to do it is to say it" (33) is to come perilously close to endorsing what might be called 'The Jimmy Carter Theory of Sin'. It will be remembered that, in a Playboy interview, he admitted that he had been unfaithful to his wife because he had lusted after other women in his mind. It may be a cause for serious concern and censure that men have sexist (though not sexual) thoughts and fantasies about women, but it would surely be taking matters too far to suggest that 'to think it is to do it, and to do it is to think it'. While the thought may be parent to the act, they are not the same thing and ought not to be treated as such.

In making this claim, it is important to emphasize that I do not say this as a matter of universal or incontrovertible fact. To do so would be to fall victim to the same error for which I have been at pains to criticize MacKinnon. While I believe the claim to be true, it has to be read within an understanding of truth as being congruent with a discursive construction of meaning. Truth and its meaning are framed through deliberation. As such, the political challenge is to democratize the discursive process, not to define its essential nature. As one of the postmodern precursors put it, "there are no facts, only interpretations" and "the world ... has no meaning behind it, but countless meanings." To hold to the view that there are only words does not amount to an abdication of responsibility for facts and the world's meanings. On the contrary, it can work to reinforce the very immediate responsibility that people have for the language and vocabularies through which they actualize the world in which they live and what are considered to be facts about it. In recognizing the constructedness of the world's meanings, the crucial challenge is, on the one hand, to resist "the lust to rule" which seeks to compel others to accept a particular view of the world "as a norm" and, on the other hand, to ensure that in doing so, one does not succumb to another manifestation of "the lust to rule."

\section{IV.}

If discourse governs reality, then it becomes imperative to ascertain whose discourse governs at any particular time and in any particular situation. As MacKinnon says, "speech can be an exercise of power which constructs the social reality in which people live."(31). It is here that her views begin to bite. She does some of her best work in exposing the exercise of men's power over women's lives. She is unrelenting in her determination to unravel the patriarchal threads of the social

23. See R. Delgado, "Words That Wound: A Tort Action For Racial Insults, Epithets, and NameCalling" (1982) 17 Harv. C.R-C.L. L. Rev. 133 and M. Matsuda, "Public Response To Racist Speech: Considering The Victim's Story" (1989) 87 Mich. L. Rev. 2320.

24. F. Nietzsche, The Will to Power, trans. W. Kaufman \& R.J Hollingdale (London: Wiedenfeld \& Nicolson, c. 1967).

25. Ibid. 
fabric. When it comes to law, she gives a new and powerful twist to Holmes' famous apothegm - "the life of the law has not been logic; it has been the experience of men." For her, the law has assumed the male experience as its own and turned it into the natural or neutral account of human experience. In overt and clandestine ways, the law represents and validates men's experience. It does this both substantively and theoretically: not only is the content of the law male, but its thinking is male. Law's power and prestige derives from its success at achieving this objectification through a denial of its very happening-the male point of view has effected and effaced itself as no point of view at all. Moreover, the law's apparent defence of freedom has often facilitated rather than curbed the corrupting influence of economic (and, therefore, male) power: 'free speech' is never free in its availability nor its consequences (74-82). For MacKinnon, law is the domination of patriarchy writ official.

In MacKinnon's world of gender relations, relations between men and women are structured around a dynamic of sexual violence in which "women exist in a context of terror"26 Domination is the inescapable order of the day and sex is an unmitigated war in which violation - "a penis ramming into a vagina" (23)-is the defining characteristic. Sex and sexual abuse are treated as indistinguishable; it is a relation in which "men may dominate and women must submit."2 Within this sordid reality, there is little to distinguish prostitution from marriage and violent assault from consensual sex; romance and rape walk hand in hand down history's boulevards. For MacKinnon, the social roles of men and women are fixed by this violent dynamic: sexuality is eroticized inequality and sexual pleasure is a perverse achievement that is inextricably caught in a demeaning spiral of male dominance and female submission. Whereas all men are violent predators who get off on women's aggressive violation, "all women have had no choice but to be identified and limited and used."28 Heterosexual encounters are a one-dimensional terrain where men actualize their potential as irrepressible rapists and women await their realization as hapless victims. Indeed, in such a patriarchal world, women are not only abused in what passes for sex, but "once [they] are used for sex, [they] ... lose [their] human status" (67).

As a thematic observation and general conclusion, MacKinnon's account is potent and pervasive. Her uncompromising work has changed profoundly the sexual cartography of the jurisprudential landscape. As depicted by MacKinnon, sexual relations are an infernal occurrence of Dante-esque proportions; erotic pleasure is as elusive as sexual inequality is endemic. However, in seeking to drive home her argument, MacKinnon succumbs to the temptation to represent the discourse

26. MacKinnon, State, supra note 3 at 151. See, also, A. Dworkin, Intercourse (New York: Free Press, 1987) and C. Littleton, "Feminist Jurisprudence: The Difference Method Makes" (1989) 41 Stan. L. Rev. 751.

27. Feminism, supra, note 3 at 3. On the whole idea of sex as violence, see MacKinnon, State, supra note 3 at 172-83. Her account is almost completely heterosexual in focus and implication. Gay, Iesbian or bisexual relations are some secondary and derivative other. In condemning the barbarity of heterosexuality, she manages to privilege it as the essence of sexual relations and the hallmark of human identity.

28. Feminism, supra note 3 at 12. 
of patriarchy as much more hegemonic and totalizing than it actually is. Again, she allows her ideological commitment to eclipse her intellectual good sense to the detriment of her political ambitions. MacKinnon is right that violence against women is not aberrational or pathological; it is a staple feature of contemporary gender relations. Moreover, it is reasonable to assume that all men, even those who decry it and desist from it, benefit from the prevalence of abuse because women become more vulnerable and acquiescent to male advances. ${ }^{2}$ Nevertheless, although sexual violence is a significant dimension and explanatory force of contemporary society, the relations between men and women are not reducible in some essential or necessary way to such a simple and flat narrative. The experiences of pleasure and oppression are much more nuanced and much less tractable than MacKinnon reports; celibacy, masturbation and rape are not the only alternatives. Women (and men) may be trapped creatures in the iron cage of patriarchy, but its socio-legal bars are not as secure nor as closed as MacKinnon would have us believe.

In MacKinnon's scenario, there are only banal Barbie and Ken stereotypes into which all the differences and diversity that mark women and men are shoehorned. There is no room in MacKinnon's world for heterosexual dominatrixs, lesbian sadists, gay masochists or the like. At best, these deviant characters are falsely conscious sexual actors who are acting out the obligatory two-role drama of heterosexual domination. Moreover, gender identity is the primary hallmark of people's lives. Although people's class, race, ethnicity and the like might influence and modulate sexual encounters, they are distinctly peripheral and secondary in their impact. Gender is the primary and primeval force at work in sex matters. Social life comprises the inevitable enactment of a vicious script in which men and women conform to the "deterministic divine will" of a patriarchal playwright." For MacKinnon, the raper and the raped exist prior to any act and, therefore, all they do is play out their scripted roles. There is no sense in which they can be in control of their own lives and fates: men cannot escape their performances as rapists and women can only wait to be violated. Each seems to be fulfilled and confirmed in their humanity through such sexual violence.

Yet such an account proves too much for its own feminist good. In making the case for the thoroughness and pervasiveness of women's oppression, MacKinnon has obliterated any idea or possibility of what it is to be a woman. Although she attests to the pain of women's lives and explains how extant social conditions diminish their potential for self-realization, her complete ascription of women's lives and thoughts and actions to the power of patriarchy is problematic. For MacKinnon, women are what men have allowed them to be, have created them to be and want them to be. This pervasive characterization of women's lives as socially constructed by and for the desire of men leaves no space for women to escape. Resignation and passivity is all there seems to be. If women's subordination is as complete as MacKinnon claims, it must be too complete for women to change. In fact, if the

29. For a different account of this claim from a heterosexual male perspoctive, see D. Kennedy, Sexy Dressing Etc. (Cambridge, MA: Harvard University Press, 1993) at 137.

30. J. Butler, Gender Trouble: Feminism and the Subversion of Identity (Nev York: Routledge, 1990) at 28. 
dominance over women is so perfected, women would never have recognized that it existed; self-consciousness would be a trait that is only available to men. As one writer has noted, " [e]ither the social construction of reality cannot be sealed hermetically, potentially challenging MacKinnon's radical rejection of objectivity, or feminist consciousness remains a mystery."31

Within MacKinnon's erotic taxonomy, there are only three kinds of women who can claim to experience sexual pleasure-the intimidated 'Linda Lovelace', the deluded 'Phyllis Schlafly', and the collaborationist 'Nadine Strossen'. ${ }^{32}$ In each case, the experience of sexual pleasure is simulated or illusory because it is inauthenticated by the existence of male domination. While there are no doubt many examples of each kind of woman, it is doubtful that the multiplicity of women's identity and sexual experience can be reduced to a tripartite schema in which all women are united in their status as victims of sexual violence and are only divided in the circumstances of their submission to it. It is surely problematic to assert that each woman's sexual experience with different men is essentially the same and can be meaningfully gathered under the rubric 'rape' ${ }^{33}$ While the attainment of sexual pleasure is always precarious and problematic in a sexist society, it is surely exaggerated to suggest that such pleasure is never attainable and that what individual women experience as sexual pleasure is actually the sensation of being raped. The fact that present laws fail to do an effective job at distinguishing between consensual sex and rape is no reason to maintain that there is no important or viable difference between the two.

Of course, some (and, of course, one is too many) women are intimidated and brutalized into subordination by, for and to men. But any account of women's oppression that gains so much of its theoretical purchase from its depiction of women as duped or pusillanimous victims is to be resisted. Many women are diminished and slighted by such a patronizing explanation. Not only does it deny the diversity of women's experience, but MacKinnon's account impugns the courage and achievement of those women who have seen through society's patriarchal rationalizations and dedicated themselves to challenging them in whatever way they can. This group of women includes heroines of the past and the present luminaries of the women's movement, including MacKinnon herself, but it is predominantly populated by those unheralded women who, conscious of their oppression as women, lived and continue to live their personal and private lives in the most empowered way that their social circumstances allow. Hemmed in and constrained by the deprivations of class and race, they are not the dupes of a misogynist mindset.

31. D. Réaume, "The Social Construction of Women and the Possibility of Change: Unmodified Feminism Revisited" (1992) 5 Can. J. of Women and Law 463 at 472.

32. See Feminism, supra note 3 at 205. A similar view is offered in A. Dworkin, Right-Wing Women (New York: G.P. Putnam, 1982) at 227-31 and Intercourse, supra note 26 at 143 . For a defence of a 'weak' version of MacKinnon's essentialism, see E. Rapaport, "Generalizing Gender: Reason and Essence in the Legal Thought of Catharine MacKinnon" in L. Antony \& C. Witt, eds, A Mind of One's Own: Feminist Essays on Reason \& Objectivity (Boulder: Westview Press, Inc., 1993) 127.

33. See K. Jackson, "Catharine MacKinnon and Feminist Jurisprudence: A Critical Appraisal" (1992) 19 J. Law \& Soc'y 195 at 202. 
In this regard, the feminist debate on sex trade workers is telling." MacKinnon is adamant that 'prostitution' is not only the quintessential practice of female exploitation and inequality, but it is also the paradigmatic instance of sexual pleasure-male dominance and female submission-in modem society. However, other women contend that, while its present circumstances may be dangerous and discriminatory, there is nothing intrinsically exploited or misguided about women who choose to empower themselves and escape poverty by "selling what they have to sell." ${ }^{35}$ Not all women who engage in the sex trade (and pornography) are "poor, desperate, homeless, pimped women who were sexually abused as children" (20). Of course, there are many such women, but there are also others, like Xaviera Hollander and Heidi Fleiss, who do not fit that description and who, if exploited, are less exploited than many other women and men. Proclaiming all sex trade workers to be falsely conscious and victims of their own deluded rationalizations is difficult to sustain. It runs close to the dubious and infantilizing 'we know best' line that women have heard from men for too long. The issue of sex trade workers is much more complicated than MacKinnon allows and the ideal reform of prostitution laws is more an inescapable contextual dilemma than a theoretical fait accompli- "to resist the commodification of women's sexuality, which requires circumscribing choices that some women themselves insist are voluntary, or to support the right of women to do the work they say they want to do, at the cost of reinforcing male dominance." ${ }^{\text {"36 }}$

Perhaps more pertinently, an unanticipated consequence of MacKinnon's claim that patriarchal power is pervasive and that women's oppression is a wall-to-wall experience is that her own work would be severely compromised. Under a strict interpretation of her writings, there are only two possible conclusions to be drawn about the validity of her own work and neither of them is realistic or sustainable. One is that the pall of dominance is as impenetrable as she suggests, such that her own theory is fatally undermined as an accurate diagnosis or prognosis of women's experience: MacKinnon's account becomes a male theory that is presented by a woman. Alternatively, MacKinnon can be read as making the audacious claim that she is (one of) the only women able to escape the very patriarchy whose pervasiveness her theory is devoted to demonstrating: she has somehow managed to acquire a point of view outside what she claims is the all-embracing male point of view. In blunt terms, the central question has to be:-How is MacKinnon able to know, in regard to prostitution, rape or sex generally, what all other women do

34. I deliberately use 'sex trade workers' instead of 'prostitution' as the later carries too much moral baggage. On the debate generally, see C. Pateman, The Sexual Contract (Stanford, CA: Stanford University Press, 1988); C. Pateman, "Defending Prostitution: Charges against Ericsson" in C. Sunstein, ed., Feminism \& Political Theory (Chicago: University of Chicago Press, 1990) 201; L. Shrage, "Should Feminists Oppose Prostitution?" in Sunstein, ed., ibid. at 185; E. Giobbe, "Confronting the Liberal Lies About Prostitution" in D. Leidholt \& J. Raymond, eds, The Sextal Liberals and the Attack on Feminism (New York: Pergamon Press, 1990) 67; and M. Baldwin. "Split at the Root: Prostitution And Feminist Discourses Of Law Reform" (1992) 5 Yale J. of L. and Feminism 47.

35. M. Radin, "Market-Inalienability" (1987) 100 Harv. L. Rev. 1849 at 1916.

36. J. Freeman, "The Feminist Debate Over Prostitution Reform: Prostitutes' Rights Groups, Radieal Feminists, and the (Im)possibility of Consent" (1990) 5 Berk. Women's LJ. 75 at 76. 
not know and what many actually deny to be the case?

The fact is that MacKinnon's work does not permit her to make any consistent or cogent answer to that question. If she claims to know what other women cannot know, she has to concede that male domination is not as perfected as she argues that it is. However, if she insists that male domination is total, she undercuts the very epistemological ground from which she claims to write. The answer is that MacKinnon is both right and wrong. She is right in arguing that patriarchy is pervasive, but wrong in arguing that it is perfected. Furthermore, she is wrong in arguing that she has a unique privilege or insight, but right in arguing that many women are not aware of their oppressed condition. In short, MacKinnon overstates the hegemony of patriarchy and runs perilously close to grounding her analysis of women's oppression in a notion of 'essential womanhood'. Her account is so flat, static and all-embracing that there is no space or opening from which to launch any transformative action: she can only chronicle the sources and strategies of victimization rather than provide explanations that themselves can become forms and founts of resistance. ${ }^{37}$ For MacKinnon, domination becomes a seamless web that is total in its intelligibility and, being bereft of complexity and contradiction, is exclusionary in its politics.

While people live in a disciplinary society, they are never entirely disciplined. The conditioning codes of sexual normality are never quite as successful as MacKinnon would have us believe. Although women and men are not the fully free and autonomous choosing selves that liberalism pretends, they are not the fully captive and manipulated foils that MacKinnon implies. The social script constrains people's choices, but the choices made transform the script and, therefore, people in small, yet significant ways. Unlike in MacKinnon's limited political vocabulary, freedom is not about the retrieval of some stifled identity or the revival of a golden age of innocence in which sexual relations were unencumbered by the constitutive culture of pornographic images and patriarchal ideas. She persists in supposing that there is a pre-social, supra-cultural and free woman who, labouring under false consciousness, is constantly trying to throw off the yoke of male domination. Her texts and critique are structured around the idea of "women's point of view" and "women's voice" which must be released if society is to give women "really what they want" and "on [their] own terms." "3s In the attempt to give women a voice of their own, MacKinnon insists that it will not be possible until substantive change is made in social arrangements as well as in men's and women's way of thinking because, at present, "his foot is on her throat." ${ }^{39}$ In short, the MacKinnon women reside outside speech in some pre-linguistic space and reality, awaiting expressive release.

In a postmodern discourse, personal freedom is more about the collective estab-

37. See C. Smart, "Law's Power, The Sexed Body, and Feminist Discourse" (1990) 17 J. Law \& Soc'y 194 at 208.

38. MacKinnon, Feminism, supra note 3 at $88,91,160,195,83$ and 22. See, also, R. Colkcr, "Feminism, Sexuality and Self: A Preliminary Inquiry into the Politics of Authenticity" (1988) 68 Boston U. L. Rev. 217 (1988).

39. Ibid. at 74 and 75 . 
lishment of a new social script in which there are roles for men and women that enable them to explore different gendered identities and sexual experiences: "[outcasts invent] new moral identities for themselves by getting semantic authority over themselves. ${ }^{.40}$ The political ambition is for women to construct voices in which they can give expression to the previously unarticulated speech of women's lives and sexuality. There is no core woman waiting to be discovered or unearthed. MacKinnon's under-the-feet-of-men women would more likely stay down since they would have no idea of how to get up or what to do if they did. By resisting the more-than-uniform history of women's experience and the less-than-totalizing effect of men's domination, MacKinnon's rhetorical devices and one-dimensional plots inhibit the prospects and possibilities for change. The challenge is to work towards those rare moments in which, as Mackinnon concedes, "[s]ex feeling good ... may mean that one has glimpsed freedom, a rare and valuable and contradictory event."1 This does not entail a denial of the fact that such sexual relations take place within a misogynist culture. It accepts that, within such a social experience, the only way to transform sexual relations is "by continually rethinking who we are and why we are making the choices we make can we free ourselves from the belief that our selves are constructed by our sexual identities."12

All of this is nowhere better illustrated than in MacKinnon's own personal life." She has been involved in a much-publicized relationship with Jeffrey Masson who has made no secret of his younger years as a compulsive womanizer. Printed in popular magazines, photographs of MacKinnon and Masson in traditional romantic poses that represent the epitome of adoring lovers speak volumes about the obvious passion that radiates between the two. So besotted are the two that they are engaged to be married. For many critics and supporters of MacKinnon, this was the stuff of high dudgeon and low betrayal. She had become the very woman that she had chastised over the years in her writings: the deluded woman who believed that she had found happiness and contentment with an adoring man-'It's like living with God. She just sits and thinks deep thoughts. She is the greatest mind at work in the world today."'s Although this is indeed an unexpected turm of events in the MacKinnon scheme of things, it does give credence to the postmodern belief that everything is up for grabs and that, while not everything will happen, anything just might happen.

More important than the fact of the relationship is MacKinnon's own response to her romantic courtship. Asked about how she could justify marriage in a society

40. R. Rorty, "Feminism And Pragmatism" (1990) 30(2) Mich. Q. Rev. 231 at 249.

41. Feminism, supra note 3 at 218 .

42. Frug, supra note 11 at 107. For a powerful and eloquent, if a little naive, antidote to Mackinnon's pessimism, see S. Tisdale, Talk Dirty to Me: A Personal Philosophy of Sex (New Yorke Doubleday, 1994).

43. It is with some obvious hesitation that I approach the personal aspects of Mackinnon's life. However, I refer only to facts and circumstances that she herself has put into the public forum through interviews and statements that she has made. After all, MacKinnon has done much to popularise the feminist credo that "the personal is political." On the relation between the lives of writers and their writings, see Hutchinson, supre note 5.

44. Masson, as quoted in Smith, "Love Is Strange: The Crusading Feminist and The Repentant Womanizer" New York (22 March 1993). 
in which she had characterised equal relations between men and women as impossible, her reply was succinct and to the postmodern point-"Does one not have relations simply because society is hierarchical? We do our best. He's not not a man and I'm not not a woman." As And this is exactly the kind of interpretive indeterminacy, categorical non-essentialism and existential confusion to which a postmodern perspective draws attention. It does not do this as a theoretical ploy and even less as a political recommendation. It is simply part of its non-foundational and non-essentialist account of living and thinking about living. Social life is messy and cannot be reduced to any simple or universal account of what it is to be a woman (or a man). Any attempt, including MacKinnon's, to contain the history and practice of sexual relations within one overarching narrative is destined to fail. As MacKinnon's own life and writings so superbly illustrate, people change the social script as they live their lives through it and seek to challenge it. Life is a drama - sometimes a tragedy, sometimes a comedy, sometimes a farce, but always theatrical in its limiting parameters and its transformative possibilities.

V.

For MacKinnon, there is a clear and uncontestable connection between pornography and rape. When she is not arguing that "pornography is no less an act than the rape and torture it represents" (29) and is "a sex act in itself" (58), she is insistent that there is a direct and unmediated causal relation between men's consumption of pornography and their infliction of harm on women. It is her position that "the evidence of the harm of [pornographic] materials ... shows that these materials change attitudes and impel behaviors in ways that are unique in their extent and devastating in their consequences" (37). Moreover, she goes so far as to assert that "the physical response to pornography is nearly a universal conditioned male reaction, whether they like or agree with what the materials say or not" (37). Based on such an instrumental account of pornography's effects, it is not surprising that MacKinnon concludes that pornography should not only be deprived of constitutional protection, but that it should be the target of legal censorship. ${ }^{46}$

The problem with MacKinnon's account is that it is too reductionist and simplistic. The relation between one social practice and another is complex and contingent. As part of a dynamic historical process, it cannot be described once and for all in terms of a universal social law. ${ }^{47}$ To attempt to discover a crude Newtonianlike nexus between social patterns of events and occurrences is to engage in a philosophically futile and politically suspect search. Even as depicted in the scientific language of causation, the physical world is probabilistic and continuous, not unique

45. MacKinnon, as quoted in Smith, ibid.

46. For an account of MacKinnon's efforts to introduce a law against pornography, see A. Dworkin \& C. MacKinnon, Pomography and Civil Rights: A New Day for Women's Equality (Minneapolis, MN: Organizing Against Pomography, 1988).

47. For a general critique of such causal claims about pornography, see V. Burstyn, ed., Women Against Censorship (Vancouver: Douglas \& McIntyre, 1985); L. Segal \& M. Macintosh, cds, Sex Exposed: Sexuality and the Pomography Debate (London: Virago Press, 1992) and P. Gibson \& R. Gibson, eds, Dirty Looks: Women, Pornography, Power (London: BFI Publishing, 1993). 
and dichotomous. The unfathomable interaction of different causes prevents the isolation of particular causes for particular injuries: the best that can be achieved is a general correlation of acts and consequences in terms of their statistical aggregation so as to establish a rebuttable hypothesis of probabilistic generality. When it comes to the world of human living, society is in such constant flux that its operation cannot be reduced to one formulaic narrative. Moreover, for any theory of social causality to carry any explanatory clout, it must be able to account for the intentions and motivations of social actors: people are not billiard balls in a cosmic game of snooker.

On some occasions of violence against women, pornography will be a weighty factor; on other occasions, it will play no part. Indeed, it might be that, in some instances, pornography provides an outlet for some men that assuages their sexual desires and prevents further violence against women. ${ }^{43}$ This possibility, of course, speaks to the larger proposition that pornography might be a symptom of a sexist society rather than, as MacKinnon seems to suggest, its major cause. Pornography can be seen as mirroring the violence that goes on, both feeding it and feeding on it. Why is it that societies that lack a pornography industry as such also have traditions and practices of violence against women? While pornography can exacerbate and partially legitimate those practices, it is doubtful that it generates and originates them. Other images contribute to a social milieu in which women are devalued and, therefore, vulnerable to unequal treatment; the stereotype of the "economic man' and its idealized feminine other is as detrimental as the tumescent 'stud' and its nymphomaniac other. ${ }^{49}$ Furthermore, MacKinnon's instrumentalist account shares the same kind of fundamentalist assumptions that encourage some reactionaries to argue that the exposure to homosexual people and ideas is the cause of children growing up to become gays and lesbians.

Nevertheless, although MacKinnon's instrumental view of the relation between pornographic cause and rape effect is discredited, it does not mean that the explanation of any correlation between the two is not possible: to think that would be to imagine that MacKinnon's billiard-ball theory of cause-and-effect is the only useful or most meaningful one in play. The impact of pornography on women is better understood in more contextual and less absolutist terms..$^{\circ}$ Because pornography always stands in need of interpretation, its meaning is too contingent and contextual to underwrite any general causative description of its effect on particular acts of violence against women. As a discourse, pornography and its effects have to be understood in the only way that they can be-discursively. Discourse constitutes the reality that we try to apprehend through that discourse. While neither determinate nor free-standing in its meanings, pornography is a social resource through which men and women assume and constitute their sexual identities and

48. See P. Gillan, "Therapeutic Uses of Obscenity" in R. Dhavan \& C. Davies, eds, Censorship and Obscenity (London: M. Robertson, 1978).

49. See Thelma McCormack, "If Pornography is the Theory, Is Inequality the Practice?" (1993) 23 Phil. of Soc. Sc. 298

50. See Bettina Quistgaard, "Pornography, Harm and Censorship: A Feminist (Re)Vision of the Right to Freedom of Expression" (1993) 52 U. Tor. L.J. 132. 
desires. Its effects and consequences will vary with its social setting and historical context in the same way that its causes and motivations will vary. As a discourse of violence, some kinds of pornography can inculcate a set of social constructs that project sexual pleasure and misogynist violence as mutually reinforcing.

While pornography can and does cause harm to women, the effect of pornography is not as universal in its extent or as uniform in its consequences as MacKinnon claims. The same pornographic material will have different effects at different times, in different places and for different people. The dissemination of certain images and representations in certain situations might be productive of social styles and sexual identities that normalize violence against women: a steady diet of violent pornography to very young children would seem to be a very hazardous course of instruction about sex. While the effect of pornography is not rape, it does contribute to a social practice in which some men can be desensitized to the nature of abuse and the harm that it does. ${ }^{51}$ It can be a formative influence in the kind of society that makes such acts more thinkable and realisable. Pornography will not be the cause-a sine qua non - but one that goes into the mix that cannot be isolated in its effect nor negatived as a possible cause. Pornography does not operate as a one-on-one individualized phenomenon that causes a particular man to rape a particular woman, but it can generate a social environment in which women are devalued as a group and sex is presented as eroticized violence through which men gratify themselves.

Accordingly, pornography has no necessary or inherent meaning. Like anything and everything else, it stands in need of interpretation and those interpretations will not be reducible to the kind of blanket condemnation that MacKinnon levels. For instance, while MacKinnon sees nothing other than demeaning images and portrayals of violated women, other women contend that it can -although not in any necessary or inherent way-" [validate] a range of female sexuality that is wider and truer than that legitimated by the non-pornographic culture."s2 To resist this challenge to her essentialist and one-dimensional account of pornography and its effects, MacKinnon has to fall back again on the elite view that, while she (and presumably similar like-minded women) can speak truth to pornographic power, other women cannot be trusted with its corrupting influence. But this, as I have already sought to show, has profound and disturbing consequences for the validity of her general theorizing about male hegemony and jeopardizes her whole campaign against pornography. ${ }^{53}$

However, it is in her claims about the effects that pornography has on men that MacKinnon is at her most essentialist and outrageous. For example, in explaining the "nearly ... universal male reaction" to pornography, she makes the claim that "[t]here is a lot wider variation in men's conscious attitudes toward pornography

51. See C. Itzin, ed., Pornography: Women, Violence and Civil Liberties (Oxford: Oxford University Press, 1992) at 201-398.

52. R. West, "The Feminist-Conservative Anti-Pomography Alliance and the 1986 Attomey General's Commission on Pornography Report" [1987] A.B.F. Res. J. 681 at 696. See, also, S. Munt, ed., New Lesbian Criticism: Literany and Cultural Readings (New York: Harvester Wheatsheaf, 1992).

53. Above in text at pages $120-124$. 
than there is in their sexual responses to it" (37). This is a truly sweeping claim about the uniformity of men's violent reaction to pornography. All men, regardless of age, education, physical ability, class, ethnicity, and especially sexual orientation (!), are captive to their non-conscious appetites. Indeed, it is so sweeping that it seems to almost exonerate men from any genuine responsibility for their actions. In MacKinnon's portrayal, all men are reduced to little more than Pavlov's dogs, sexual beasts who can neither resist nor reform their violent tendencies to all women. It is simply part of the biological urge that comes from being born with male genitalia. But this is to reduce sex to biology and to reject the idea of the socially constructed nature of gender and sexuality to which much feminism, including MacKinnon's, is committed.

To contend that MacKinnon's account of pornography's causality is a caricature is not to deny that men are violent to women or that pomography is harmful. But it is to question MacKinnon's account as a way of understanding and, most importantly, changing the situation in which violence against women is far too commonplace in contemporary society. Contrary to her intentions, MacKinnon manages to reify the patriarchal script of history and to make its continued performance almost inevitable. She casts reality as being outside discourse and, therefore, almost beyond people's control and transformation. Nothing necessarily follows from exposure to pornography. In the same way that reading 'good books' is not guaranteed to make better people, watching pomography is not certain to make worse people."A In contrast to MacKinnon's essentialism, a postmodern politics insists on treating experience as contingent rather than metaphysical: it talks in terms of likelihoods, not certainties. By doing so, it ensures that experience is always within politics (and therefore open to re-appropriation and re-valorisation by women) and not outside politics (and therefore closed to women's transformative action). Accordingly, because a clean break from extant practices is not possible, the postmodern challenge is to accept the political code and social systematization of patriarchy not so as to comply with it, but to disrupt and destabilize it.

VI.

Persuaded that pornography has no redeeming values and is an unmitigated threat to women's self-realisation, MacKinnon is firmly of the view that official steps must be taken to expunge it from society. However, it is more than a little ironic that, while most of her work is scathing about existing law, she puts her trust in the very legal institutions and judicial personnel that she maintains have been a prime force in holding patriarchy in place. Presumably, though, the law is no less patriarchal in its logic and reasoning when its content is changed. Indeed, the text of any law does not speak for itself and must be interpreted within law's patriarchal context. As the historical experience with the First Amendment readily demonstrates, there is no guarantee that constitutional provisions and legal rules that were apparently introduced to benefit any particular group will not be interpreted or

54. See Fish, supra note 14 at 31-50 and Hutchinson, supra note 5 at 1195-1202. 
enforced against their interests. Although MacKinnon prefaces her writings with the caution that they are "not an idealist argument that law can solve the problems of the world,"ss they do tend to be schizophrenic about law's capacity and willingness to effect wholesale change.

In turning to law as a primary mode for combatting pornography, there are very real dangers that attend its interpretation and enforcement. One general possibility is that the banning and demonization of pornography may validate and normalize the other sexist images that populate the pages and screen of popular entertainment. Because they are not stamped with the mark of criminality, such representations might be deemed to be appropriate and non-problematic. Indeed, the measure of a society's misogyny might be better gauged by the available images and identities for women that are considered acceptable. Mindful of the insidious exercise of power through discourse, the fact that the stock characters which are portrayed and projected in the mainstream media, such as the housewife, the mistress and the martyr, are so limited and limiting might give advocates of censorship pause. Moreover, the criminalization or actionability of pornography is unlikely to put an end to its practice. If the demand is as great as MacKinnon suggests, it will continue to thrive as an underground operation; this would give even more scope to the racketeers and extortionists and place them outside the law rather than inside it. It should not be forgotten that prostitution is no less prevalent and no more safe for women because its practice is largely criminalized.

Notwithstanding this, the larger danger is that, no matter how honourable or politically correct are the motivations of its proponents, such official powers of censorship are difficult to control and monitor. There is a tendency for such powerful weapons to be deployed indiscriminately or against the most vulnerable in society. In the establishment of such official powers, its supporters have to be convinced that they are not simply supplying weapons to their political enemies and strengthening their already ample arsenal. This is particularly so for those groups, again like feminists, who want to use censorship to challenge, not confirm, entrenched networks of power. It is difficult to understand why a patriarchal state, when enhanced in its powers, would be likely to use them to castrate itself. Too often, censorship is used as a disciplinary tactic to protect established interests and curb the actions and ideas of those, again like feminists, devoted to social change. ${ }^{36}$

A good example of these dangers of censorship can be found in the events that surrounded and followed the decision of the Supreme Court of Canada in the case of Butler. ${ }^{57}$ The Court had to decide whether the charges against a pornography store owner under the Criminal Code's anti-obscenity provisions were an unconstitutional restriction on his Charter right to freedom of expression. Following its earlier decision on hate propaganda in Keegstra, ${ }^{\text {ss }}$ the Court held that the owner's

55. State, supra note 3 at xiii. See, also, Feminism, supra note 3 at 26.

56. See D. Downs, The New Politics of Pornography (Chicago: University of Chicago Press, 1989). 57. R. v. Butler, [1992] I S.C.R. 452.

58. R. v. Keegstra, [1990] 3 S.C.R. 697. In both this case and Butler, MacKinnon contributed to the brief of the Women's Legal Education and Action Fund (LEAF) which took a line that was almost pure MacKinnon in its general structure and intellectual thrust. 
rights had not been infringed and that his conviction stood. MacKinnon waxes enthusiastic about these decisions (97-105). However, apart from having a bad case of The-Grass-Is-Greener-In-Canada Syndrome in claiming that "[m]aybe in Canada, people talk to each other, rather than buy and sell each other as ideas" (102) ${ }_{2}^{59}$ she seems almost wilfully blind to the doctrinal basis for the decision and its political aftermath. Rather than provide support for MacKinnon's position and contentions, the Butler affair exposes their precarious and risky politics on several counts.

First, while MacKinnon is right in maintaining that the Supreme Court stood "behind a comparatively powerless group in its social fight for equality against socially powerful and exploitative groups" (103), she lets her enthusiasm get the better of her when she concludes that the Court "recognized the reality of inequality in the issues before it" (103). In both Keegstra and Butler, it was held that pornography was speech and that the right to freedom of expression had been infringed, but that criminalization of hate propaganda and obscenity was permissible under the Charter's 'reasonable limits' clause. The majority of the Court in both cases took it as a given that freedom of expression was the dominant value and that the Charter's equality guarantee should not be used to limit or interpret that right. Indeed, the judges went so far as to declare that recourse to the values of equality was only important as a buttress to the 'reasonable limits' analysis. ${ }^{\infty}$ Of course, MacKinnon is free to argue that, "properly interpreted" (103), the obscenity and hate propaganda laws are about equality, but this is a very long stretch from the Court's judgments and contradicts many of the judges' own explicit understandings. While MacKinnon's might be a better or more useful interpretation, it was not the one that the Court thought that it was making.

Secondly, MacKinnon argues that "[n]either Canadian decision reduces the harm of hate propaganda or pornography to its 'offensiveness'" (104). Stressing that "[h] ate speech and pornography ... enact the abuse" (104), she insists that Keegstra and Butler are not about morals and manners, but politics and power. However, while the Butler decision is ostensibly about suppressing pornography to prevent harm to women, it has a disturbing sub-text that represents a more traditional and less open sexual morality. ${ }^{61}$ It reinforces the dominant and disciplinary discourse of Western sexuality in which sex is bad, shameful and redeemable only if it transcends its base nature and confines itself to the heterosexual frame of reference.

59. I do not want to be read as saying that Canada is no different from the United States. I think that MacKinnon is probably right in thinking that things are not as bad in Canada, but this is more a matter of degree than kind. It is entirely too romantic to suggest that Canadians are not in thrall to 'the marketplace of ideas' and its attendant ideology. Sec A. Hutchinson, Wairing for CORAF: A Critique of Law and Rights (forthcoming, 1995).

60. Keegstra, supra note 58 at 733-34 and 755-57 per Dickson C.J. and Butler, supra note 57 at 490 93 per Sopinka J. However, the court did accept that there was a causal connoction between pomography and harm to women. See P. Hogg, Constirutional Law of Canada, 3rd od. (Toronto: Carswell, 1992) at 977-79. In Keegstra, the minority was even more dismissive of equality concerns and held that the Charter's equality provision was not applicable at all to speech matters. Ibid. at 804 per McLachlin J. For a different reading of Keegstra, see Fish, supre note 14 at 104-05.

61. Brenda Cossman, "Feminist Fashion or Morality in Drag?: The Sexual Subtext of The Butler Decision" (Feb. 1994). Unpublished. 
Although the law has clothed itself in the voguish garments of MacKinnonesque feminism, it is little more than a repressive "sexual morality in drag." MacKinnon's interpretation is not thereby rendered wrong, inaccurate or untenable-it is simply not right, accurate or exclusive in the way that she claims it to be.

Also, the fact that Butler is open to multiple readings does not itself undermine MacKinnon's argument. But, as she should realise, any legal victory can be quickly neutralized by bureaucratic inertia, political intransigence, judicial complacency and rank prejudice. ${ }^{63}$ The potential multiplicity of interpretations is reduced to one actual interpretation by official or powerful agents when they fix a law or a ruling's meaning for citizens. Sadly, MacKinnon's optimism that "the Canadian law of equality is moored in the world, and knows the difference between disadvantaged groups and advantaged ones" (103) is dashed by the uses to which the anti-obscenity laws have been put. Since Butler, it is not the peddlers of violent pornography against women that have been targeted by the authorities. The first subsequent two criminal prosecutions for obscenity were brought against a gay and lesbian bookstore. ${ }^{64}$ The allegedly obscene publications did not depict violence or exploitative sex, but consensual sex between people of the same gender. Of course, neither Butler nor MacKinnon brought about these custom seizures: they have been going on for years. But Butler did tend to validate such practices. These prosecutions are a convincing illustration of how power combines with 'offensiveness' to cliscipline relatively vulnerable and powerless 'deviant' groups by enforcing the conventional norms of acceptable behaviour. It is a chilling scenario that MacKinnon and others ignore at their peril. Indeed, the fact that some of Andrea Dworkin's books have been temporarily detained supports, not undermines, this claim.

VII.

Despite her protestations to the contrary, MacKinnon's theorising is of a very traditional and classical kind. She struggles to gain a vantage point that will allow her to report, if not from nowhere, the view from everywhere. Her political diagnosis and prescriptive program rests on an account of social living that derives its philosophical validity from a discredited set of metaphysical assumptions and ontological suppositions. The different fragments and seams of Only Words are held together by an essentialist narrative thread about the nature of women, men and their sexual experiences. Unfortunately, this is because MacKinnon persists in the

62. Ibid. at 2 .

63. D. Bell, And We are Not Saved: The Elusive Quest for Racial Justice (New York: Basic Books, 1987) at 25-74, 140-61 and 215-35.

64. See Glad Day Bookshop Inc. v. Deputy Minister of National Revenue (Customs \& Excisc) (July 14, 1992), Doc. 619/90 (Ont. Gen. Div.) and R. v. Scythes (January 16, 1993), Paris J. (Ont. Prov. Div.). For a general discussion, see Cossman, supra note 61 and D. Barclay, "Obscenity ChillArtists In A Post-Butler Era" (1993) 16 Fuse 2. The main action has been through customs seizures rather than criminal prosecutions. See S. Chernos, "Little Sister's Still Up Against Big Brother" (Dec 1993) This Magazine 6 and R. Hough, "Degrading Customs" Globe and Mail (12 Feb. 1994) D-1 and 5. 
belief that the philosopher's task is to lay down authoritative blueprints for political action in the name of some universal truth about the human condition. She cannot seem to abandon the belief that worth and prestige derives from "knowing something about knowing which nobody else knows so well." In the starkest terms, MacKinnon contends that there is a Truth to Women's Experience that has been suppressed by the Falsity of Pornography which causes violence against women. As such, it is her self-imposed responsibility to speak Feminist Truth to Patriarchal Power.

Contrary to common expectations, replacing this classical mode of philosophizing with a more postmodern demeanour will not inhibit her from speaking 'feminist truth to patriarchal power'. What it will do is oblige her to take a less essentialist and more contextual approach to 'feminist truth' and 'patriarchal power'. It would oblige her to accept that the idea that there can be an escape to somewhere or something that can give an incontestable foundation to further and future negotiations over feminist truth and patriarchal power is a profoundly political claim that is itself never beyond contestation or debate. There is no non-political place-whether it is science, philosophy, history, experience, human nature or whatever-to which people can retire to ground their political interventions. Like truth and reality, politics is itself a discursive practice in which the play of power occurs. There is no outside to the world of words and no final escape from the finitude of politics. Rather than continue as an abstract practice of intellectual deep-sea diving in which the ambition is to touch bottom and drop social anchor once-and-for-all, philosophizing must become more self-consciously an active practice of learning to swim with the turtles: ${ }^{6}$

Where does this leave the debate on pornography? And where does it leave MacKinnon's critical ideas and her practical contributions to that debate? The answer is as simple as it is straightforward-where they have always been: on the complex and contested terrain of politics. Nothing will necessarily have been lost or gained. It most certainly does not mean that MacKinnon's writings must be jettisoned or discarded. However, in throwing overboard her metaphysical baggage, MacKinnon might be prepared to reconsider her essentialist message and absolutist solutions. In doing so, she might deliver a more nuanced and less totalizing account of women's lives that could garner and galvanize greater intellectual and political support: a foundationalist and fundamentalist theory of law and oppression inhibits and compromises a truly transformative politics. ${ }^{67}$ Stripped of its essentialist trappings, her reduction of all gender interaction to the universal and irresistible dynamic of female exploitation and male dominance is almost guaranteed to resign people to despair and disempowerment rather than to inspire them to resistance

65. Rorty, supra note 10 at 392 . Like law and legal theory, philosophy is an authoritarian business. See M. Walzer, "Philosophy and Democracy" (1981) 9 Pol. Theory 379.

66. This is a reference to the familiar story about the universe being "turtles all the way down" which has become something of a chestnut in jurisprudential contexts. See J. Singer, "Radical Moderation" [1985] A.B.F. Res. J. 329 at 329-30. For a more extended account of the attitudes and beliefs that comprise postmodernism, see A. Hutchinson, Swimming Wiht Turfles: Law; Politics and Postmodernism (forthcoming).

67. C. Vance, "Feminist Fundamentalism-Women Against Images" (1993) 29 Art In Ameriea 36. 
and transformation. Such a monolithic theory of oppression ensures that, to stand any chance of success, the nature of change will have to be revolutionary and tyrannical. This not only makes it highly unlikely, but it runs the risk of curing the illness by killing the patient. While desperate situations require desperate measures, the defeat of tyrannous regimes by tyrannous means is no victory at all. Censorship is an admission of weakness that entrenches the powerlessness of women as it strengthens the hand of the patriarchal state. It does not empower women in their own right nor does it allow the creation of a space within which to resist and realign the misogynist discourse of contemporary society.

MacKinnon seems to believe that the taking of a postmodern perspective will only reinforce the "indifference to violence against those people on the bottom" (31) because "[p]ostmodernism ... cannot grasp, or has forgotten, or is predicated on obscuring, this [rationalizing and normalizing] function of language in social hierarchy" (123). This is a familiar refrain. Whereas the fear from the 'right' is that postmodernism is nihilistic and razes everything to the ground, the fear from the 'left' is that it is "febrile and flippant" and leaves everything as it is..$^{\text {ss }}$ Yet nothing follows as a matter of logic or necessity: postmodernism is neither apocalyptic nor apologetic. By becoming more postmodern, MacKinnon will have neither sharpened nor blunted the edge of her political critique. As I have tried to demonstrate, postmodernism does not turn a deaf ear to language's political function, but insists that its clear and unavoidable truth is better heard. However, if MacKinnon is concerned that it offers no programmatic or practical prescriptions, she is right. There is no postmodern method or manifesto in the sense of a process that can be followed that will produce and vouchsafe particular results; it is an attitude and a temperament to political engagement.

Nevertheless, if by method one means something as prosaic as a way of proceeding, then there are certain lessons for political action and agitation that postmodernism can offer: it denies the univocity of meaning and urges the plurality of interpretation; it realises that people are never entirely masters of what they say and always partners in the negotiation of meaning; it abandons the preoccupation with universalizable claims and encourages greater attention to social context; it rejects the need for an overarching narrative of political change and accepts the worth of local attempts at transformation; it eschews the taking up of 'right' and 'left' ideological sides and recognises that politics is diffusely multi-sided; it does not view freedom as a splendid isolation, but as a socially-sustained web of relationships; it understands that identity is something that is made and re-made, not given and accepted; it emphasizes that, while people are always situated and constrained, they are never completely saturated or contained; and it emphasizes that social justice is never a once-and-for-all achievement, but a continuing responsibility to keep the question of justice open. All that postmodernism can ultimately

68. See, for example, P. Goodrich, "Sleeping With The Enemy: An Essay on the Politics of Critical Legal Studies in America" (1993) 68 N. Y. U. L. Rev. 389 at 396 . But what would amount to a truly radical politics that did not slide into the safety of pipe-dreaming or the terror of armed struggle? For an outline of how politics can be both visionary and postmodem, see A. Hutchinson, "Doing The Right Thing? Toward A Postmodern Politics" (1992) 26 L. \& Soc'y Rev. 773. 
do is to reassure people that things need not be the way that they are, that change will always occur, that it is for each person to work for change and that what amounts to better and worse changes is never uncontestable. Of course, this is a dangerous business because a postmodern perspective on law, politics and social change is subversive and always risks the worst. There are no guarantees that the 'right' side or what amounts to the right side will carry the day. However, the 'wrong' side will only carry the day. In a postmodern world, tomorrow is always another political day and another occasion to transform society and its contingent politics. Not only will people live to fight another day, but they live in order to fight another day.

A commitment to such a postmodern perspective is not tantamount to a denial that contemporary society is patriarchal in its sweep and substance or that pornography can be productive of violence against women. But it is to affirm the possibility that society and social life need not be that way. In particular, it reassures people that sex can be more than an aggressive invasion of a woman by a man and that an erect penis is not always a tool of oppression. As MacKinnon herself demonstrates, such a strategy is no more risky than the day-to-day business of living for many women in contemporary society. Indeed, a shift to a postmodem outlook can multiply the sites for resistance to the present order. It is an acknowledgement of pornography's discursive indeterminacy that presents the most viable and effective opportunity for strategic intervention and transformation. Indeed, pomography has occasionally been used as a potent form of dissent to religious and political authority. ${ }^{69}$ Its irrepressible openness to multiple interpretations and meanings render it susceptible to alternative readings and deployment to those that presently dominate. Women can begin to explore the discursive possibilities and experiment with new vocabularies that give voice to a broader range of sexual desires and pleasures. Unlike in MacKinnon's account, pornography can be seen as much as another organic site for continued political struggle and future revalorization as a toxic dump which can only be filled in and kept off limits.

Of course, in saying this, I am not arguing that all sexually-explicit representations are good; that would be to take the same essentialist position as MacKinnon. Nor do I think that they are all bad and pornographic. Depending on the context, some are good and some are bad. To be anti-censorship is not to be pro-pornography: this is a ludicrous drawing of ideological lines that distorts and disables any political position. As with all disputed social practices, there is no safe or secure political ground on which to stand or from which to intervene in the pornography debate. As a political engagement, it is always an unstable and shifting medium. Whichever way one turns, there will be trade-offs to be made. To defend sexuallyexplicit representations against legislative prohibition is to be on the side of the pornography industry and its commercialization of all sex. On the other hand, to oppose sexually-explicit representations is to be on the side of the Moral Majority and its related campaign against abortion, gays, lesbians, etc. Accordingly, the

69. See Lynn Hunt, ed., The Imvention of Pomography: Obscenity and the Origins of Modeminy I5001800 (New York: Zone Books, 1993). 
struggle over pornography is not usefully or effectively carried out by prohibiting it entirely. A more progressive and postmodern strategy is effected by appropriating and revamping the discourse of pornography so that it can be turned into a democratic discourse of political dissent and sexual diversity, not a privileged monologue of men's frustration and women's oppression. The challenge is to re-think and reinvent the nature and diversity of sexual activity by developing more discursive identities and empowering vocabulary that emphasise "what makes sex a good and positive dimension to our humanity."70

Catharine MacKinnon is a little reminiscent of Holden Caulfield. In vain efforts to protect his sister, Phoebe, from obscene graffiti, he goes around erasing them from walls and buildings. " Instead of explaining to her why they were there and what discontent they represent, he labours under the naive hope that, by effacing them, the obscene ideas and the people who held them would simply disappear as well. While Caulfield and MacKinnon's wish is laudable and defensible, their way of proceeding is misguided and too head-in-the-sand to support or condone. For instance, her plea to reconsider pornography law and sexual practices "in terms of specific experiences, the particularity of history, substantively rather than abstractly" (109) is exactly what is required and exactly what MacKinnon fails to do. Instead of being a nuanced and context-sensitive exploration, she commits a flat and sweeping indictment of men, women and sex throughout history and across societies. Moreover, she seeks to correct it by an equally flat and sweeping solution. She would do much better to pay greater attention to the practices and protocols of power that frame and infuse our experience of sex. If her aim is to create "a context of repose into which thought can expand, an invitation that gives speech its shape, an opening to a new conversation" $(110)$, Only Words is unlikely to be read as an invitation that can realistically establish a context of repose in which a new conversation can be opened. MacKinnon tends to stifle debate rather than encourage it.

In the profoundest sense, a postmodern approach would be the best complement to MacKinnon's desires. It takes seriously the importance of context, speech and renewed conversation in matters of sex and sexual pleasure. Its commitment is to ensuring that the social culture of people's lives is a playful context in which they can constantly re-shape themselves and the speech that comprises that culture. The invocation of 'play' is not meant to trivialize sex or violence against women, but to enlarge the space in which otherness can be encompassed and explored. By treating sex as the ultimate postmodern space of instability in which the conflicts of power are beyond absolute determination, jouissance might be given its fullest expression. In a social space in which freedom and repression are continually renegotiated and re-situated, it might be possible to achieve a precarious, but exhilarating experience of authentic sexual pleasure that, as MacKinnon puts it, "may mean that one has glimpsed freedom, a rare and valuable and contradictory event."

70. Cossman, supra note 61 at 35 .

71. J.D. Salinger, The Catcher in the Rye (New York: Modern Library, 1945).

72. Feminism, supra note 3 at 218. 
In this way, sexuality can become an activity through which people confirm themselves in their humanity and its limitless possibilities rather than, as MacKinnon suggests, an encounter in which men and women are seemingly obliged to subjugate their own human potential. It is not so much that 'anything goes' in a postmodem world, but that 'anything might go'. ${ }^{3}$

\section{VIII.}

A few years ago, I was invited to speak at the University of Michigan Law School. It was shortly after Catharine MacKinnon had been appointed to the faculty. After the lecture, a group of students took me out to a local bar for a drink. At the end of the evening, while we were getting our coats on, one student turned wearily to another and said-“"Are you having sex with MacKinnon in the morning?" I spun around at this only to hear the other student say, with a heavy sigh,- "Naw, I can't be bothered." I was momentarily dumbfounded by this desultory exchange, until I realised that "sex with MacKinnon" referred to Catherine MacKinnon's class on 'Sex Equality' the next morning at the law school. In a simple and unaffected way, the students had fallen into abbreviating her course to 'Sex' with little thought of how this might sound to the uninformed outsider. To them, at least in this conversation, the expression 'Sex' was as mundane and unexceptional as 'Crim' and 'BizAs' are as references to other classes. I laughed to myself.

As a former colleague and continuing admirer of Catharine MacKinnon's work, I felt a twinge of guilt at my laughter and misunderstanding. Humour about and around sex is a treacherous minefield of political explosives. ${ }^{24}$ Nevertheless, I did laugh, but the fact that I did it "to myself" was evidence of my discomfort and unsureness. I was careful to whom I told the incident on my return home and about how I told the story. Anecdotes or stories that tend to sexualize women academics are understandably fraught with risk: Romano's review is the illustration par excellence. Nevertheless, mindful that her students were likely sympathetic to and supportive of MacKinnon's ideas, their unintended double entendre offers a telling and pertinent illustration of the contingent and contextual sense of meaning-that words have no intrinsic and independent meaning of their own, that meaning shifts and varies with context, and that context is never transparent to itself such that its limits and implications are themselves beyond interpretation. In short, there is nothing beyond, below, behind or above interpretation, but more interpretation. Meaning is always available and determinable, but never settled or determined. Indeed, the import and meaning of my 'Michigan incident' is open and never outside of politics; neither I (nor anyone else) can claim any fixed or essential meaning for it.

Pornography, of course, is not funny. And Catharine MacKinnon's writings

73. Kennedy, supra note 29 at 184.

74. While humour can be socially disruptive and politically liberating, it is too often the chosen medium for cowards and bigots to make slurs that are not as conveniently or acceptably expressed in other modes of speech. It is a disciplinary code and any failure to laugh is often met by the derisory - "don't you have a sense of humour?" Sce D. Collom, Text and Culture: The Politics of Interpretation (Minneapolis: University of Minnesota Press, 1989) at 3-48. 
against pornography are not a laughing matter. They are earnest and uncompromising in their focus and commitment to eradicating pornography and violence against women. But they are also too acontextual and essentialist to be intellectually persuasive and politically convincing. As my 'Michigan incident' was intended to show, words have no intrinsic or abiding meaning; they are beholden to their context for any semblance of hermeneutical force. Of course, the context is itself never stable or self-delineating: it can only be apprehended and understood through words. Was the fact that a man asked the question-_"Are you having sex with MacKinnon in the morning?"-and a woman replied-'Naw, I can't be bothered"-relevant? In other words, those words neither are nor are not right, wrong, funny, offensive, exploitative, liberating or whatever. Similarly, any sexually-explicit representation expression is neither bad nor good, harmful nor ameliorating, abusive nor empowering: the feminist Not A Love Story frames a sexually-explicit image in a very different context than the pornographic Deep Throat. The words and images themselves say nothing in, of and for themselves. It is all about context. And, because contexts are themselves discursive, words are inescapable. In other words, it is only words. And that is to say everything, not nothing. 